\title{
OIL TRANSPORT AND PROTECTING CLEAN WATER: THE CASE OF THE DAKOTA ACCESS PIPELINE (DAPL)
}

\author{
George W. White ${ }^{1}$, Bruce V. Millett ${ }^{2}$
}

Keywords: Oil transport, clean water, environment, United States

\begin{abstract}
Oil frequently plays a crucial role in modern industrial economies. It is a very costly natural resource for those countries that do not have it, but very profitable for those that do. Yet, developing oil resources and transporting them to market has its own costs, not only in terms of production but also in terms of impacts on other valuable natural resources such as clean water. Not surprisingly, governments can have strict environmental regulations concerning oil transport. However, such regulations can be complicated, especially in countries like the United States where many different government agencies claim jurisdiction, especially at differing spatial scales. Consequently, conflict can result from competing interests, pitting those developing oil resources against those already using resources such as clean water. This paper explores the complicated geographies of environmental regulations and how competing entities pursue and protect their interests through environmental ligation. In doing so, this study uses the example of the Dakota Access Pipeline (the DAPL) because the conflict surrounding it garnered considerable national and international attention.
\end{abstract}

\section{Introduction}

In June 2016, a company known as Dakota Access, LLC, a subsidiary of Dallas-based Energy Transfer Partners, L.P., began construction of an oil pipeline called the Dakota Access Pipeline (DAPL). This pipeline extended from the Bakken and Three Forks shale oil fields in northwest North Dakota to Patoka, Illinois (Energy Transfer Partners, L.P., 2017), a distance of 1,886 km (Figure 1).

${ }^{1}$ Professor, Ph.D., South Dakota State University, Department of Geography, George.White@sdstate.edu

${ }^{2}$ Assistant Professor, Ph.D., South Dakota State University, Department of Geography, Bruce.Millett@sdstate.edu 
After completion in June 2017, the DAPL became part of a network of more than 3.8 million kilometers of energy pipelines in the United States. However, the DAPL also became one of the most contested oil pipelines in recent U.S. history as landowners, environmentalists, Native Americans, and oil companies conflicted over land use rights. Much research has focused on how the DAPL violated Native American rights (Estes, 2019; Finley-Brook et al., 2018; Harrison, 2018; Nicholescu, 2018; Marincic, 2018; Mitchell, 2019; Privott, 2019). Other research has examined how social media was employed to resist the DAPL (Bosworth, 2019, Deem, 2018; Martini, 2018; McNeil \& Thorntonm, 2017; Smith, 2019; Smith \& van Ierland, 2018). Noteworthy, little light has been shed on the approval process, which typically involve both privately-owned- and public-owned properties. The process of obtaining permission to cross each of type of owned land differs. In fact, the approval process is complicated and to the extent that it may exacerbate the conflicts between differing land uses. Further research would elucidate the approval process for oil pipelines to better explain the conflicts that result. This research provides a relevant analysis of the approval process to reveal one of the contributing factors to the contested nature of the DAPL and to other conflicts surrounding other energy pipelines that sometimes emerge.

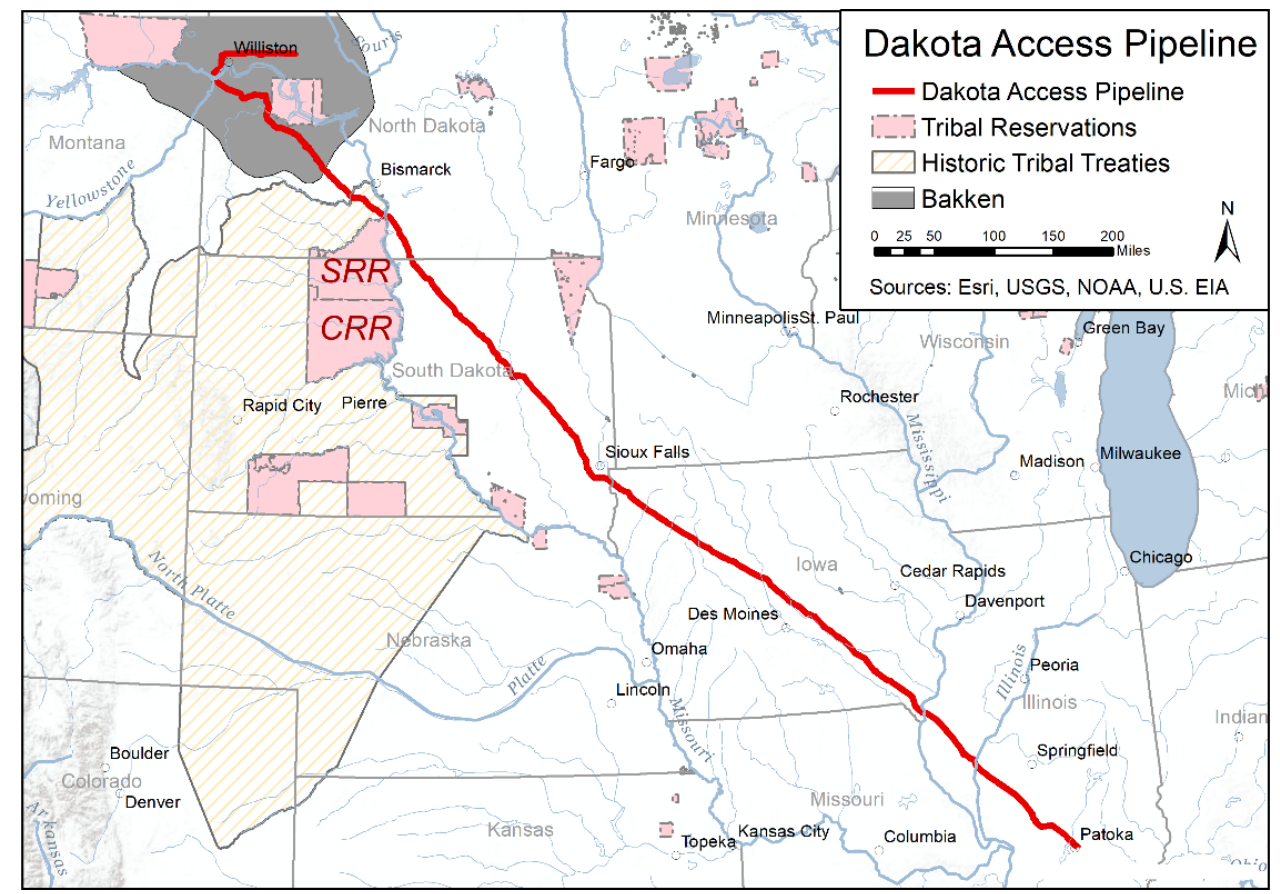

Fig. 1. The route of the Dakota Access Pipeline (DAPL) 


\section{Land Acquisition}

1.1. Private property and eminent domain. Oil pipelines require access to continuous sets of properties from their production sites to their delivery destinations. A pipeline with a length of $1,886 \mathrm{~km}$ easily can cross more than 1,000 different properties. A company such as Dakota Access, LLC can purchase the necessary properties or purchase the rights from landowners to lay the pipeline on their properties. Purchasing the rights is usually cheaper and thus the preferred method. Either way, 100 percent of the property owners must accept the terms because a single holdout would leave a gap in the pipeline, making the pipeline nonfunctional. However, achieving 100 percent agreement is a difficult task, especially when hundreds or thousands of property owners are involved. Any one of them could resist for various reasons. For example, they may fear the contamination of their soil and/or water, that an oil pipeline will lower their property's value (i.e., price), or that an oil pipeline might diminish their other economic uses of their properties. Moreover, some property owners may resist selling land or permission with the hope that they eventually will obtain a very high price. Because failure to obtain a single property can end an entire project, a landowner may believe that he or she could obtain a price far higher than he or she could obtain from someone wanting the land for other uses. For example, an oil company would presumably have far more money to pay for a property to reap the profits from an oil pipeline than a person or another entity would have to buy the land for farming.

If 100 percent consent from property owners was required for such projects as oil and water pipelines and electricity, communication, and transportation lines (e.g., roads, railways), then the United States would have far less of such infrastructure as exists today. The process of eminent domain (also known as condemnation) allows the government to obtain property for public use. Such an act is seen as a right of any sovereign government (Find Law, 2019a). However, the Fifth Amendment of the United States' Constitution states that "No person shall be deprived of life, liberty, or property without due process of law; nor shall private property be taken for public use, without just compensation" (Find Law, 2019b). At the same time, the Fifth Amendment gives states the ability to set their own specific requirements for eminent domain within the federal definition of the concept.

The Dakota Access Pipeline (DAPL) was constructed across four states: North Dakota, South Dakota, Iowa, and Illinois. In these and most states, property owners are entitled to receive 100 percent of the fair market value for their properties. However, the idea of "just compensation" varies geographically. For example, North Dakota allows each property owner to know what at least 10 neighboring property owners are offered for their properties to complete a project. The property 
owner also is entitled to receive a copy of the map identifying other landowners in the same county or neighboring counties who must surrender their land for a project and receive a list of those landowners (Stenehjem, 2019). The intent behind these particular rules is to establish fair market value. Another example where "just compensation" is employed differently is Iowa, where Iowa's state government allows property owners to receive compensation at 130 percent of an appraisal amount of their properties (Biersdorf \& Associates, 2019; U.S. Legal, 2019).

Resistance also has its varied geographies. For example, in May 2016, in response to Dakota Access, LLC pursuit of eminent domain for the DAPL, Iowa farmers filed two lawsuits (McMaken, 2016; Petroski, 2016). They argued that Dakota Access, LLC was not a utility and, therefore, had no right to pursue eminent domain cases against their properties. Fifteen other landowners also filed a lawsuit, arguing that the pipeline was not in the public interest. They argued that the oil pipeline was only to the interest and benefit of a single company, especially because the oil was to be exported and not used in Iowa. Despite their arguments, a Polk County judge ruled that Dakota Access, LLC had such a right (Hardy, 2017).

\subsection{Public Lands and governmental approval}

Not all lands are privately held. Some lands are publicly held and require the permission of governmental agencies before infrastructure such as oil pipelines can be built across them. In fact, many infrastructural projects require permission of governmental agencies whether or not they cross publicly- or privately-held lands. For example, Energy Transfer Partners, L.P. was required to gain approval of several federal agencies in order to build the DAPL. One of these agencies was the FERC (Federal Energy Regulation Commission), which "is an independent agency that regulates the interstate transmission of electricity, natural gas, and oil" (Federal Energy Regulation Commission (FERC), 2018). Whether or not other federal agencies must give their approval for an oil pipeline depends on the types of land that an oil pipeline will cross. In the case of the Dakota Access Pipeline (DAPL) and the lands that it crosses, these federal agencies have jurisdiction: the United States Army Corps of Engineers (USACE), the United States Fish and Wildlife Service (USFWS), the Environmental Protection Agency (EPA), and the Advisory Council on Historic Preservation (ACHP). The USACE is particularly important because it regulates and manages waterways and specifically is concerned with such issues as the planning, designing, building, and operating of locks, dams, and flood control structures. As part its mission, the USACE also regulates the natural environment and restores ecosystems. Because the proposed DAPL crosses at least nine major waterways (Gilpin, 2016), the USACE had to assess its environmental impact. However, its decisions pitted the DAPL and its builder against those who draw clean water from rivers, namely Native Americans. Also, the route of the DAPL and its construction potentially violated Native treaty 
rights and potentially desecrated Native American religious sites. This latter issue concerned the Advisory Council on Historic Preservation (ACHP).

\section{Competing Interests and Contestation}

As part of the planning process for the DAPL, Dakota Access, LLC submitted its route plan to the United States Army Corps of Engineers (USACE) with the intent of obtaining the USACE's approval of its route plan. Interactions between Dakota Access, LLC and the USACE eventually established a route for the DAPL. The route included a crossing under Lake Oahe on the Missouri River, for which the USACE gave its permission on 25 July 2016 (Figure 2). This location was near the town of Cannon Ball in North Dakota and also less than one kilometer from Standing Rock Indian Reservation, many of whose members opposed the location of the oil pipeline. Standing Rock tribal members had two major concerns. The

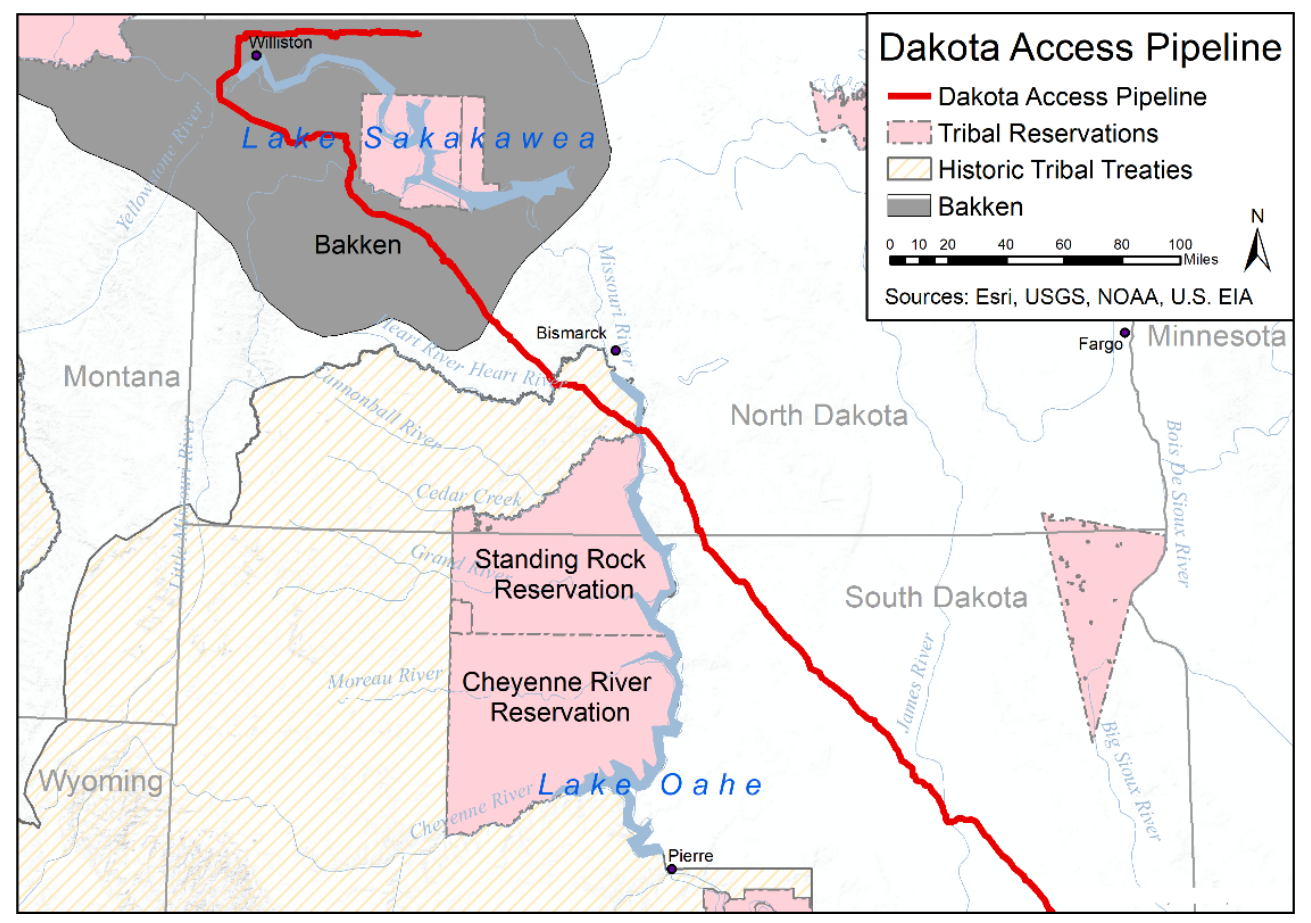

Fig. 2. The Dakota Access Pipeline's (DAPL) crossing of Lake Oahe on the Missouri River.

first was that oil leaks in the DAPL would contaminate the water supply of Standing Rock, which drew its water from Lake Oahe on the Missouri River. The 
second was that a portion of the DAPL passed through sacred Indian lands and that the DAPL and its construction would destroy "ancient burial sites, places of prayer and other significant cultural artifacts of the Standing Rock Sioux Tribe" (Indian Country Today 2016).

To protect its use of clean water and its historic tribal lands, Standing Rock Tribe, with legal support from the nongovernmental organization (NGO) known as Earth Justice, filed a lawsuit on 27 July 2016 against the USACE for violating the National Environmental Protection Act (NEPA), the National Historic Preservation Act (NHPA), the Clean Water Act (CWA), and the Rivers and Harbors Act (RHA) (Parker, 2018). (The purposes and key texts of these Acts are provided in Table 1). On 28 July, Dakota Access, LLC filed a motion to join the USACE as a defendant, which the court granted on 8 August. On 10 August, Cheyenne River Sioux Tribe, which also draws its water from the Missouri River, filed a motion to join the lawsuit and was granted permission to do so by the court on 19 August. On 8 September, Cheyenne River Sioux Tribe amended its complaint, alleging similar complaints as Standing Rock Reservation. In addition, the Cheyenne River Sioux Tribe also claimed that the USACE's granting of permission to the DAPL also violated the Fort Laramie Treaty of 1851, the Sioux Nation Treaty of 1868, and the Flood Control Act of 1944 (Parker, 2018). While the DAPL passed near the current boundaries of Standing Rock Reservation, the Fort Laramie Treaty of 1851 granted much more land to the Sioux Tribes, an area of land that included the neighboring sacred sites and sections of land where the DAPL was being constructed. Invoking this Treaty was a means of illustrating that the DAPL violated tribal lands (see Figure 2).

Table 1. U.S. Governmental Acts

\begin{tabular}{|c|c|}
\hline Act & Key Text \\
\hline $\begin{array}{l}\text { Rivers } \\
\text { Harbors } \\
\text { (RHA) of } 1899 \\
\text { (Section 10 is the } \\
\text { responsibility of } \\
\text { the USACE) }\end{array}$ & $\begin{array}{l}\text { "An Act Making appropriations for the construction, repair, and } \\
\text { preservation of certain public works on rivers and harbors, and for } \\
\text { other purposes." }\end{array}$ \\
\hline $\begin{array}{l}\text { Mineral Leasing } \\
\text { Act of } 1920\end{array}$ & $\begin{array}{l}\text { "To promote the mining of coal, phosphate, oil, oil shale, gas and } \\
\text { sodium on the public domain."" }\end{array}$ \\
\hline $\begin{array}{l}\text { Flood Control Act } \\
\text { of } 1944\end{array}$ & $\begin{array}{l}\text { "The Act authorized the construction of thousands of dams and } \\
\text { levies across the U.S. It also established changes in policies relating } \\
\text { to flood control. . . . [It] managed the Missouri River with six } \\
\text { intents: hydropower, recreation, water supply, navigation, flood } \\
\text { control and fish and wildlife." }\end{array}$ \\
\hline
\end{tabular}




\begin{tabular}{|c|c|}
\hline $\begin{array}{l}\text { National Historic } \\
\text { Preservation Act } \\
\text { (NHPA) of } 1966\end{array}$ & $\begin{array}{l}\text { "The historical and cultural foundations of the Nation should be } \\
\text { preserved as a living part of our community life and development in } \\
\text { order to give a sense of orientation to the American people ... the } \\
\text { preservation of this irreplaceable heritage is in the public interest so } \\
\text { that its vital legacy of cultural, educational, aesthetic, inspirational, } \\
\text { economic, and energy benefits will be maintained and enriched for } \\
\text { future generations of Americans"4 } \\
\text { [the Federal government] "in partnership with States, local } \\
\text { governments, Indian tribes, and private organizations and } \\
\text { individuals to...use measures, including financial and technical } \\
\text { assistance, to foster conditions under which our modern society and } \\
\text { our prehistoric and historic resources can exist in productive } \\
\text { harmony and fulfill the social, economic, and other requirements of } \\
\text { present and future generations (Section } 2 \text { (1)).". }\end{array}$ \\
\hline $\begin{array}{l}\text { National } \\
\text { Environmental } \\
\text { Policy Act } \\
\text { (NEPA) (1970) }\end{array}$ & $\begin{array}{l}\text { "The National Environmental Policy Act (NEPA) was enacted to: } \\
\text { declare a national policy which will encourage productive and } \\
\text { enjoyable harmony between man and his environment; to promote } \\
\text { efforts which will prevent or eliminate damage to the environment } \\
\text { and biosphere and stimulate the health and welfare of man; to } \\
\text { enrich the understanding of the ecological systems and natural } \\
\text { resources important to the Nation; and to establish a Council on } \\
\text { Environmental Quality. Sec. } 2 \text { [42 U.S. Code } \S 4321 \text { ]." }\end{array}$ \\
\hline $\begin{array}{l}\text { Clean Water Act } \\
\text { (CWA) (1972) }\end{array}$ & $\begin{array}{l}\text { "The Clean Water Act (CWA) establishes the basic structure for } \\
\text { regulating discharges of pollutants into the waters of the United } \\
\text { States and regulating quality standards for surface waters. ... } \\
\text { The CWA made it unlawful to discharge any pollutant from a point } \\
\text { source into navigable waters, unless a permit was obtained."” }\end{array}$ \\
\hline $\begin{array}{l}\text { Religious } \\
\text { Freedom } \\
\text { Restoration Act } \\
\text { (RFRA) of } 1993\end{array}$ & $\begin{array}{l}\text { "Prohibits any agency, department, or official of the United States } \\
\text { or any State (the government) from substantially burdening a } \\
\text { person's exercise of religion even if the burden results from a rule } \\
\text { of general applicability"8 }\end{array}$ \\
\hline
\end{tabular}

Table Sources:

${ }^{1}$ https://coast.noaa.gov/data/Documents/OceanLawSearch/Summary\%20of\%20Law\%20-

\%20Rivers\%20Harbors\%20Act\%20of\%201899,\%20 Section\%2010.pdf

${ }^{2}$ https://www.blm.gov/or/regulations/files/mla_1920_amendments1.pdf

${ }^{3} \mathrm{https} / /$ definitions.uslegal.com/p/pick-sloan-flood-control-act-of-1944/

${ }^{4} \mathrm{http}$ ///preservation50.org/about/nhpa-history/

${ }^{5}$ https://www.nps.gov/archeology/tools/laws/nhpa.htm

${ }^{6}$ https://ceq.doe.gov/

${ }^{7}$ https://www.epa.gov/laws-regulations/summary-clean-water-act

${ }^{8} \mathrm{https} / / /$ www.congress.gov/bill/103rd-congress/house-bill/1308 
The filing of a lawsuit began a court case that continues today and has been marked by a number of new claims, counterclaims, and cross-claims, many of which draw on seminal government acts (see Table 1). For example, on 15 November 2016, Dakota Access, LLC responded to the Cheyenne River Tribe's aforementioned complaint by stating that it had a right to build the DAPL under Lake Oahe on the Missouri River according to the Mineral Leasing Act of 1920 (Parker, 2018). At the same time, the court case has continued because the actors involved have made new decisions and taken new actions that have prompted new legal complaints.

Of all the claims, counterclaims, and cross-claims, three stand out as the most significant as each of them had the potential to halt the construction of the DAPL or shut down its operations after it began transporting oil. The first was Standing Rock Tribal Reservation's call for a preliminary injunction "based solely on the NHPA [National Historic Preservation Act], asserting that the ongoing clearing and grading of the land along DAPL's route disrupted sacred Tribal sites" (United States District Court for the District of Columbia, 2017b). However, Judge James E. Boasberg of the United States District Court for the District of Columbia denied the request. The second attempt occurred when Cheyenne River Sioux Tribe made a motion for Preliminary Injunction, claiming that the right-of-way granted for the DAPL violated the Religious Freedom Restoration Act. However, Judge Boasberg also denied this motion (United States District Court for the District of Columbia, 2017a; 2017b).

For their third attempt to stop the DAPL, the Standing Rock Sioux Tribe and its allies claimed that the USACE violated the National Environmental Protection Act (NEPA) when it opted to complete an Environmental Assessment (EA) rather an Environmental Impact Statement (EIS) (Bennett and Stern, 2017; Hasselman, 2018a). "The EA determines whether or not a federal action has the potential to cause significant environmental effects" (United States Environmental Protection Agency 2019). The EA results in two potential outcomes. One is the determination that the action "will not have significant environmental impacts". In such cases, the agency (e.g., the USACE) will issue a Finding of No Significant Impact (FONSI). However, if the agency determines that the action will have significant environmental impact, then the agency will pursue the course of an Environmental Impact Statement (EIS), which is a deeper analysis and one that requires public notification and input.

Standing Rock Sioux Tribe's allegation that the USACE violated the National Environmental Protection Act (NEPA) has had the most traction in court. Noteworthy, the USACE announced in January 2017 that it was it was preparing the Environmental Impact Statement (EIS) on DAPL's crossing of Lake Oahe on the Missouri River (Army Department, 2017a; Hersher, 2017b). However, only a 
few days later, Donald Trump became president of the United States and released an executive memorandum directing the USACE to expedite the review and approval process (The White House, Office of the Press Secretary, 2017). In early February, the USACE issued a memo stating that it was allowing the DAPL to be constructed under Lake Oahe on the Missouri River pursuant to the Mineral Leasing Act of 1920 (Hersher, 2017a; United States District Court for the District of Columbia, 2017b). In mid-February, the USACE stopped its work on an Environmental Impact Statement (EIS) in regard to the Dakota Access, LLC (Army Department, 2017b).

On 14 June, 2017, aforementioned Judge Boasberg ruled that the USACE's conclusion "that the risk of an oil spill was sufficiently low so as to not require an EIS" was reasonable (United States District Court for the District of Columbia, 2017b). In other words, the USACE “'largely complied' with environmental law when it approved the pipeline but didn't adequately consider some matters important to the Standing Rock Sioux" and required further study (Nicholson, 2017; see also EELP Staff, 2017). These matters included "impacts of a spill on hunting rights, fishing rights and environmental justices" (Kazdin, 2017). Therefore, Judge Boasberg remanded these issues back to the USACE for further study.

While the issue was on reprimand, Standing Rock and its allies filed motions to halt the operation of the DAPL until the effects of an oil could be determined. However, in an 11 October 2017 decision, Judge Boasberg allowed the DAPL to continue transporting oil because he believed the USACE would be able to justify its previous decision that the DAPL was safe through further elaboration. (The Associated Press 2017) (United States District Court for the District of Columbia, 2017b). He also noted that Standing Rock Tribe's water-intake structure had been moved 80 kilometers downstream, an act that would minimize any oil contamination of the Tribe's water supply. At the same time, the USACE stated that it would finish its assessment by 2 April 2018 (McKenna, 2017).

The USACE did not submit a new environmental analysis by 2 April. Instead, on 31 August 2018, it submitted a two-page Memorandum for Record of its additional research as remanded back to it from Judge Boasberg (Hudson, 2018). The summary concluded that "the potential impacts of an oil spill to hunting and fishing resources did not reveal any significant impacts because the risk of an incident is low and any impacts to hunting and fishing resource will be of limited scope and duration" (Hudson, 2018). The USACE addressed the environmental justice issue by stating that "the DAPL under federally-owned Corps-managed land does not result in disproportionately high and adverse human health or environmental effects on minority populations, including Tribes, and low-income populations". The summary concluded by stating that no additional "analysis or 
any new mitigation" beyond what was completed on 8 February 2017 (Hudson, 2018). On 1 October 2018, the USACE released its full 140-page report.

Dissatisfied with the USACE's conclusions, the Standing Rock Sioux Tribe filed a supplemental complaint on 1 November (Hasselman, 2018b; Standing Rock Sioux Tribe, 2018). On 3 January 2019, Judge Boasberg granted the Tribes the ability to challenge the USACE's conclusion that an oil spill from the DAPL would not unfairly affect them (Nicholson, 2019). However, he ruled that the tribes could not introduce any new claims not specifically related to the USACE's additional study. He directed the USACE until 31 January to give the tribes any information that the USACE used to its environmental assessment.

\section{Conclusions}

The court case is still pending. However, since Standing Rock Indian Reservation and its allies first initiated a court case in July 2016, they were not able to stop the construction of the DAPL or halt the transport of oil through the DAPL of oil after it was completed in June 2017. All legal challenges claim that the USACE violated federal laws as expressed in a number of governmental Acts (see Table 1) to protect the natural environment thus far have been unsuccessful. At most, Standing Rock Indian Reservation and its allies only succeeded in obtaining the court judgement that the USACE did not sufficiently justify its decision to permit the construction and operation of the DAPL. Consequently, the USACE has had to provide more written documentation of its decision. Nevertheless, according to court decision, the DAPL was constructed and is now operating according to the governmental Acts designed to protect the natural environment and the natural resources that it provides.

\section{References:}

1. Army Department (2017a), Notice of intent to prepare an environmental impact statement in connection with Dakota Access, LLC's request for an easement to cross Lake Oahe, North Dakota. Federal Register: The Daily Journal of the United States Government 18 January, https:/www.federalregister.gov/ documents/2017/01/18/201700937/notice-of-intent-to-prepare-an-environmental-impact-statement-in-connectionwith-dakota-access-llcs.

2. Army Department (2017b), Notice of termination of the intent to prepare an Environmental Impact Statement in connection with Dakota Access, LLC's request for an easement to cross Lake Oahe, North Dakota. The Daily Journal of the United States Government $\quad 17 \quad$ February, https://www.federalregister.gov/ documents/2017/02/17/2017-03204/notice-of-termination-of-the-intent-to-prepare-anenvironmental-impact-statement-in-connection-with 
Associated Press, The (2017), Judge allows Dakota Access pipeline to keep running. 11 October, https://www.voanews.com/a/judge-allows-dakota-access-pipeline-keeprunning/4066527.html

3. Bennett, D.M., Stern, W. (2017), Dakota Access Pipeline project update-Corps' NEPA Analysis flawed-in part. Lexology 22 August, https://www .lexology.com/library/detail.aspx?g=37f12b71-2e58-436e-bc57-d9bdb1175fd6

4. Biersdorf \& Associates (2019), Iowa Eminent Domain Process. https://www. condemnation-law.com/iowa-eminent-domain-attorney/process/

5. EELP Staff (2017) Dakota Access Pipeline. Harvard Law School (HLS): Environmental \& Energy Law Program 24 October, https://eelp.law.harvard .edu/ 2017/10/dakotaaccess-pipeline/

6. Bosworth, K. (2019) The people know best: Situating the Counterexpertise of populist pipeline opposition movements. Annals of the Association of American Geographers 109:2, 581-592. https://doi.org/10.1080/24694452.2018.1494538

7. Deem, A. (2018) Mediated intersections of environmental and decolonial politics in the No Dakota Access Pipeline Movement. Theory, Culture \& Society 36 (5): 113-131. https://doi.org/10.1177/0263276418807002

8. Energy Transfer Partners, L.P. (2017), Energy Transfer Announces the Bakken Pipeline is in Service Transporting Domestic Crude Oil from the Bakken/Three Forks Production Areas. 1 June, http://ir.energytransfer.com/phoenix.zhtml?c= 106094\&p=irol-newsArticle \&ID $=2278014$

9. Estes, N. (2019) Our history is the future: Standing Rock versus the Dakota Access Pipeline, and the long tradition of indigenous resistance. New York: Verso.

10. Federal Energy Regulation Commission (FERC) (2018), About FERC: What FERC does. https://www.ferc.gov/about/ferc-does.asp

11. Find Law (2019a), Annotation 14 -Fifth Amendment: National Eminent Domain Power. https://constitution.findlaw.com/amendment5/annotation14.html\#1

12. Find Law (2019b), Fifth Amendment-U.S. Constitution: Firth Amendment-Rights of Persons. https://constitution.findlaw.com/amendment5.html

13. Finley-Brook, M., Williams, T. L., Caron-Sheppard, J. A., Jaromin, M. K. (2018) critical energ ustice in natural gas infrastructuring. Energy Research \& Social Science 41:176-190. https://doi.org/10.1016/j.erss.2018.04.019

14. Gilpin, L. (2016), These maps help fill the gaps on the Dakota Access Pipeline: Meet the researcher mapping the threats to water scarcity. High Country News 5 November. https://www.hcn.org/articles/these-maps-fill-the-gap-in-informationabout-the-dakota-access-pipeline

15. Hardy, K. (2017), Dakota Access pipeline had right to take Iowa land, judge rules. Des Moines Register $15 \quad$ February, https://www.desmoinesregister.com/story/ money/business/2017/02/15/dakota-access-pipeline-had-right-take-iowa-land-judgerules/97966662/

16. Harrison S. (2019). "We need new stories": Trauma, storytelling, and the mapping of environmental injustice in Linda Hogan's solar storms and Standing Rock. American Indian Quarterly 43 (1/Winter): 1-35. DOI: 10.5250/amerindiquar.43.1.0001

17. Hasselman, J. (2018a), On the Standing Rock Sioux Tribe litigation: On the U.S. Army Corp's Aug. 31 decision on the Dakota Access Pipeline. Earth Justice, https://earthjustice.org/features/inside-the-legal-case-dapl-update 
18. Hasselman, J. (2018b), The renewed legal challenge against Dakota Access Pipeline. Earth Justice 1 November, https://earthjustice.org/features/explainer-renewed-legalchallenge-dakota-access

19. Hersher, R. (2017a), Army Approves Dakota Access Pipeline Route, Paving Way for Project's Completion. National Public Radio (NPR) 7 February, https://www.npr.org/sections/thetwo-way/2017/02/07/513951600/army-approvesdakota-access-pipeline-route-paving-way-for-the-projects-completio

20. Hersher, R. (2017b), America: Key moments in the Dakota Access Pipeline fight. National Public Radio (NPR) 22 February,https://www.npr.org/sections/thetwo -way/2017/02/22/514988040/key-moments-in-the-dakota-access-pipeline-fight

21. Hudson, J.L. (2018), Memorandum for Record. Department of the Army,Corps of Engineers, Omaha District 31 August, https://www.indianz.com/News/2018/09/ 04/usace083118.pdf

22. Indian Country Today (2016), Standing Rock Sioux Tribe condemns destruction and desecration of burial grounds. 4 September, https://newsmaven.io/indian countrytoday/archive/standing-rock-sioux-tribe-condemns-destruction-anddesecration-of-burial-grounds-tbGDUq4PW0aOVUZEiVIweA/

23. Kazdin, C. (2017) The Sioux lost a key battle in their struggle against the DAPL: The tribe's latest attempt to shut down the pipeline temporarily ended in failure. Vice 12 October, https://www.vice.com/en_us/article/paknq8/the-sioux-lost-a-key-battlein-their-struggle-against-the-dapl

24. Marincic, A. (2018). The National Historic Preservation Act: An inadequate attempt to protect the cultural and religious sites of Native Nations. Iowa Law Review 103(4): 1777-1809.

25. Martini, M. (2018). Online distant witnessing and live-streaming activism: Emerging differences in the activation of networked public. New Media \& Society 20 (11): 4035-4055. https://doi.org/10.1177/1461444818766703

26. McKenna, P. (2017), Judge orders Dakota Access Pipeline Spill Response Plan with tribe's input. Inside Climate News 5 December, https://insideclimatenews.org/news/ 05122017/dakota-access-pipeline-ruling-standing-rock-emergency-spill-response-plankeystone

27. McMaken, R. (2016), The Real Reason to Oppose the Dakota Access Pipeline. Mises Wire 29 November. https://mises.org/wire/real-reason-oppose-dakota-access-pipeline

28. McNeill, J.L., Thornton, T.F. (2017) Pipelines, petitions, and protests in thei nternet age: Exploring the human geographies of online petitions challenging proposed transcontinental Alberta oil sands pipelines. Annals of the American Association of Geographers 107 (6): 1279-1298. https://doi.org/10.1080/24694452.2017.1320212

29. Mitchell, F.M. (2019). Water (in)security and American Indian health: Social and environmental justice implications for policy, practice, and research. Public Health (January). https://doi.org/10.1016/j.puhe.2018.10.010

30. Nicholescu, I. (2018). Cases of equality: Idle no more and the protests at Standing Rock. Canadian Journal of Urban Research/Revue Canadienne de Recherche Urbaine 27(2/Winter): 1-13. https://www.jstor.org/stable/26542032 
31. Nicholson, B. (2017), Ruling on Dakota Access pipeline surprises oil industry. Houston Chronicle 15 June, https://www.houstonchronicle.com/business/ energy/article/Ruling-on-Dakota-Access-pipeline-surprises-oil-11224278.php

32. Nicholson, B. (2019), Judge allows tribe to challenge Corps' Dakota Access study. The Seattle Times 7 January, https://www.seattletimes.com/business/judge-allowstribes-to-challenge-corps-dakota-access-study/

33. Parker, J (2018), Case Name: Standing Rock Sioux Tribe v. Dakota Access (EJ-DCCi0001). Civil Rights Litigation Clearing House University of Michigan Law School 20 July. https://www.clearinghouse.net/detail.php?id=16671

34. Petroski, W. (2016), Iowa farmers sue to block use of eminent domain for Bakken pipeline. Des Moines Register 20 May, https:/www.desmoinesregister.com/story/news/ politics/2016/05/20/farmers-sue-to-block-use-of-eminent-domain/84676294/

35. Privott, M. (2019). An ethos of responsibility and indigenous women water protectors in the \#NoDAPL movement. American Indian Quarterly 43 (1): 74-100. DOI: 10.5250/amerindiquar.43.1.0074

36. Smith, C. (2019). Ironic confrontation as a mode of resistance: The Homeland Security t-shirt at the Dakota Access Pipeline protests. The American Indian Quarterly 43(3): 339-364. DOI: 10.5250/amerindiquar.43.3.0339

37. Smith, J.M., van Ierland, T. 2018. Framing controversy on social media: \#NoDAPL the debate about the Dakota Access Pipeline on Twitter. IEEE Transactions on Professional Communication 61(3): 226-241 DOI: 10.1109/TPC.2018.2833753

38. Standing Rock Sioux Tribe (2018), Standing Rock Sioux Tribe renews legal challenge against DAPL. 1 November, https:/www.standingrock.org/content/ standing-rock-sioux-tribe-renews-legal-challenge-against-dapl

39. Stenehjem,W. (2019). Landowner Rights under Eminent Domain Laws. https://attorneygeneral.nd.gov/consumer-resources/landowner-rights-under-eminentdomain-laws

40. United States District Court for the District of Columbia (2017a), Standing Rock Sioux Tribe, Plantiff, and Cheyenne River Sioux Tribe, Plaintiff-Intervenor, versus U.S. Army Corps of Engineers, Defendant, and Dakota Access, LLC, Defendant-Intervenor and Cross-Claimant: Civil Action No. 16-1534 (JEB), Document 159. 7 March, https://www.documentcloud.org/documents/3509171-170307-DenyInjunction.html

41. United States District Court for the District of Columbia (2017b), Standing Rock Sioux Tribe, Plantiff, and Cheyenne River Sioux Tribe, Plaintiff-Intervenor, versus U.S. Army Corps of Engineers, Defendant, and Dakota Access, LLC, Defendant-Intervenor and Cross-Claimant: Civil Action No. 16-1534 (JEB) (and 16-1769 and 16-267). 11 October httpsCase ://wwNos.w.indianz.com/News/2017/10/11 /04516256846.pdf

42. United States Environmental Protection Agency (2019), National Environmental PolickevAdew Process. https://www.epa.gov/nepa/national-environmental-policyact-review-process.

43. U.S. Legal (2019), Iowa Eminent Domain Laws. https://eminentdomain.uslegal .com/ state-laws-on-eminent-domain/iowa/ 
44. The White House, Office of the Press Secretary (2017), Construction of the Dakota Access Pipeline. 24 January, https://www.npr.org/assets/news/2017/01/

DakotaAccessConstruction.pdf

(C) 2020 by the authors. Licensee UAIC, Iasi, Romania. This article is an open access article distributed under the terms and conditions of the Creative Commons Attribution (CC BY-NC-ND) license (https:// creativecommons.org/licenses/by-nc-nd/4.0). 